\title{
ASEAN-CHINA ECONOMIC DISPUTE IN THE AFTERMATH OF PCA RULING ON SOUTH CHINA SEA Prita Amalia $^{1^{*}}$, Danrivanto Budhijanto ${ }^{2}$, AnAn Chandrawulan ${ }^{3}$ \\ ${ }^{1 * 2,3}$ Faculty of Law, Universitas Padjadjaran, Jalan Raya Bandung-Sumedang Jawa Barat, Indonesia. Email: "prita.amalia@ unpad.ac.id
} Article History: Received on $16^{\text {th }}$ May 2020, Revised on $15^{\text {th }}$ August 2020, Published on $26^{\text {th }}$ September 2020

\section{Abstract}

Purpose: This study aims to scrutinize existing economic dispute mechanisms between ASEAN and PRC which can promote fairness and effectivity. With examining PRC's non-compliance to PCA awards in the South China Sea case, this article aims to link between the rule-breaking action of PRC (the territorial dispute) and the preventive action of ASEAN.

Methodology: This research uses the juridical empiric method, which analyzes the dispute resolution legal framework between ASEAN and PRC.

Main Findings: ASEAN and its legal instruments were not designed to provide a fair and effective dispute resolution mechanism that can prevent both PRC's non-compliance to international law and ensure fairness in economic disputes.

Implications/Applications: Organizational behavior is important for family businesses and due to the difficult environment faced by family businesses in order to be competitive in our country and in global markets; a good option for owners is to invest in organizational behavior as a market strategy.

Novelty/Originality of this study: This study shows that the contest of ASEAN-China partnership mentioned proof that ASEAN and PRC are not yet completely separated because of the SCS issue. Based on it, a conviction should not drastically block the economic partnership of the two or destroy the bridges between different legal systems. Thus, the initiative will fundamentally promote peace and stability in the region.

Keywords: ACFTA, BRI, Dispute Resolution, Claim of South China Sea, PCA.

\section{INTRODUCTION}

The Permanent Court of Arbitration (PCA) has made a unanimous decision on the South China Sea case involving The Philippines as the claimant, and PRC as the respondent. The Court generally supported the Philippines' notion, leaving no justification for PRC territorial occupation on a part of the Pacific Ocean. Although it was the first time that PRC has been sued in an international court (Chau, 2018), it is not the first for PRC undermining international law. With the ongoing BRI project in the South East Asian Region, several issues have emerged (Cheng, 2016; Williams et al., 2019), and the current legal system is questioned, especially regarding the effectiveness of its economic dispute resolution for ASEAN member states if used against PRC. This is the reason why the dispute and ruling of PCA should attract attention from ASEAN states which have BRI deals, including municipal companies and of the states. They will be affected by the relationship between the ASEAN as an economic block and PRC after the ruling and during the dispute. BRI will have a large and significant impact beyond Asia-Pacific Region, then it will allow Beijing's greater influence on other regions (Dellios \& Ferguson, 2017), including the emerging economic power house, the ASEAN (Zhang, 2018). During this situation, the economic effect of the decision is expected to be managed by ASEAN, so it gives a minimum disruption to the economic atmosphere.

In other fields, PRC tends to act against existing international law and international organizations' concerns about world conditions, and PRC was not afraid to allow conflict to escalate. China's fundamental policy goal on the SCS issue has been consistent; safeguarding core national interest and maintaining regional peace and stability (Chen, 2016). For example, Beijing has objected to the global climate initiative and promotion of the Asian Development Bank (Ba, 2003; Sutiono, 2018). Given their powerful objection and the passive international reaction, the ruling carried only moral victory for the Philippines while the contested waters, rocks, and reefs have remained under PRC's control (Munandar \& Firmansyah, 2018; Zhao, 2018). The conflict has a different background and nature. On one hand, the South China Sea dispute shows China's military influence; it naturally ostracized many of the major trading allies in ASEAN which are important states for the Chinese objective to strengthen their economic position in ASEAN. The PCA decision gives a glimpse of a future condition that threatens the existing trade relationship between countries and regions. It shows the way how PRC resolves conflicts in the future and it hinders PRC's progress to enhance current economic cooperation. The most important thing in this regard is the RCEP (Regional Comprehensive Economic Partnership), as a desirable flatform to maximize new trade. was created intentionally by China as the world's second-largest economic power (Ye, 2015) to rival the US with its Trans-Pacific Partnership (TPP), (Booth, 2011; Taguchi, 2015). 
The concept of 'rule of law' can explain the condition between PRC and ASEAN which had its ups and downs for the past 15 years. The South China Sea dispute is a test of ASEAN unity and its ability to maintain itself in regional affairs, but it failed the test. Discussions about the relationship are largely focused on PRC's ongoing economic expansion and military conducts in the Pacific which shows the rule of international law on PRC. There are several actors in the world who are influenced by the increasing military and economic strength of PRC. Among ASEAN members, the focus on such security issues also cannot ignore the past Sino-ASEAN relations, where economic relations have been developed and improved over the decades involving mutual efforts of ASEAN and China (Booth, 2011). The analysis of a ten years period of the economic relation between PRC and ASEAN, in particular, shows that the dynamic in global relations has created important opportunities to build closer relationships, as much as those that have created some challenges. Indeed, from the great power, PRC has made the most profits in relation to Southeast Asia. Meanwhile, PRC's military strength could be seen in 2010 where its defense budget was at least three times higher than all ten ASEAN countries put together. Five years later, it stood over five times the ASEAN figure (Yahuda, 2019). Figure 1 below shows the ASEAN - PRC Trade value which has a positive trend for a decade. In 2013, when celebrating the10th commemoration of the ASEAN-China Partnership, the Prime Minister of PRC, Li Keqiang, extend a set of initiatives to enhance partnership cooperation for the next decade.

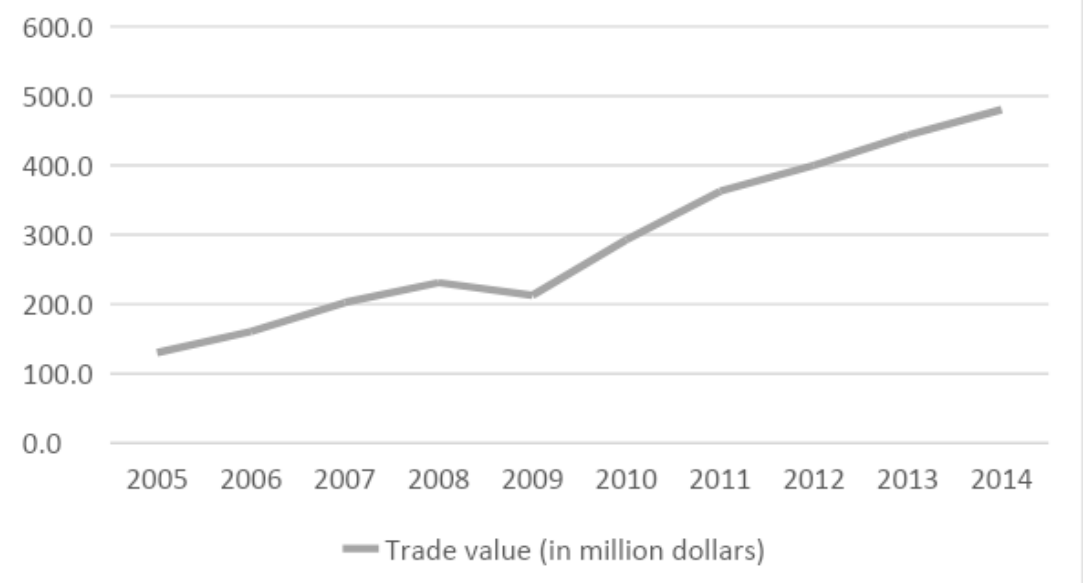

Figure 1: Asian-China Trade Data (Portal, n.d.)

Two of the strategies in the proposal are to increase trust and deepen economic cooperation (Laksmana, 2016). ASEAN consented to increase the integration process under the ASEAN-China Free Trade Agreement (ACFTA), as the regional backbone which attracts the most attention, by leveling up market access as well as balancing trade power among the two parties and expanding the scope and Framework coverage of ACFTA (Tampubolon, 2019). States participating in ACFTA established an objective to achieve USD 1 trillion for trade among them and USD 150 billion for two-way investment by 2020. In reality, the target was not easily achieved, even with growth progress over the past years (Adnyana, 2016; Sabit, 2015). The member state of ASEAN positively responded to the PRC's announcement, but the states were still vigilant, at least in two aspects (Joseph, 2001): (1) the ACFTA is accused to benefit more to the PRC side than to ASEAN side. ACFTA appeared to be advantageous just to China, and not for ASEAN countries (Alleyne et al., 2020; Wildan, et al., 2017). PRC's business reaches the ASEAN market effectively because of its competitiveness, contrary, most of the business from ASEAN members hardly can catch up with that. This has resulted in a uniformity of trade in goods deficits throughout most ASEAN states. It creates a reluctance to buy PRC goods and create hostility from local enterprises in ASEAN countries. (2) small states are drawn into a situation where their economic condition depends so much on PRC, so they have weak negotiating power on security issues. They may also lose their foreign policy autonomy against Beijing. Economic dependence is used to evade the rising of political statements opposing PRC's claim over part of the Pacific Ocean. The Philippine protests China's claims were reduced during the Duterte presidency compared to Aquino, because Duterte preferred to maintain PRC's economic relation and support, instead of acting on a PRC move for the South China Sea. So, the ACFTA or the development of the infrastructure to enhance it, as a means for increasing ASEAN-PRC trade and investment, have not yet fully translated into a pure economic strategic partnership. The absence of mutual trust among them is still a presence in ASEAN-PRC economic relations, and the effort given by China since the '90s to strengthen economic relations with the region seems not resulting in the desired output. Also, the mutual trust between the two parties regarding security issues has not increased as much as trading volumes have been (Cook, 2014). This article examines further the implication of the South China Sea situation, where several ASEAN member states became the disputing countries, to the ASEAN-China economic relation. 
ASEAN is a regional international organization according to Article 4 Charter of The Southeast Asian Nations, 2007 with ten parties: Indonesia, Brunei Darussalam, Cambodia, Laos, Malaysia, Myanmar, Philippines, Singapore, Vietnam, and Thailand. With all its diversity in the historical, cultural, political, and economic background, member states of ASEAN are collectively equal to a state which has the $7^{\text {th }}$ biggest economic power in the world (McKinsey, n.d.). The 10 ASEAN States had stated their regional economic partnership under ASEAN Economic Community since 2003 in the ASEAN Summit, Bali, Indonesia (Hew, 2007). Regional integration within the ASEAN opens the way to integrate into global economic powers, one of which is cooperation with the PRC until the regional cooperation was interrupted by the PRC' claim for the South China Sea.

Historically, PRC has had a long tradition trading with the so-called South Sea Region, which refers to countries in Southeast Asia, from a Chinese point of view. The trade-in the region was dominant under the Wu Kingdom which in rule forms 222 to - 279 AD. This continued to develop during the Dynasty of Liang from 502 to 587 AD. In the era, Funan (now parts of 3 ASEAN States which are Cambodia, Thailand, and Vietnam) acted as the main seaport for trade which connected the Mekong River to the maritime Region in the $6^{\text {th }}$ century (Hew, 2007). Long before the modern era, the South China Sea has played an important role as a 'historical junction' for vital trade routes connecting PRC, India, Europe, and Africa. The claims to the South China Sea came from this historic facts that Chinese traders and sailors stopped on two islands in the South China Sea: Paracel and Spratly islands (in which PRC has taken over the control of the two islands by building military facilities including a military airstrip and defense system) while crossing the South China Sea on a commercial trip (O'Rourke, 2016). However, PRC's claim over massively South China Sea Region irrelevant with the existing international law of these stipulated in The 1982 United Nations Convention on the Law of the Sea (UNCLOS).

Philippines brought the dispute under Chapter VII of UNCLOS 1982 as the basis for PCA to have jurisdiction. PRC was unwilling to cooperate and refused to accept the PCA jurisdiction. This could not stop PCA to hear the case since PRC has signed UNCLOS 1982 and has an international obligation to accept Chapter VII. PCA then made its decision based on the international law of the sea and leaving no justification for PRC's sea territorial claim (Schofield, 2016). PRC claims unprecedented historic rights' to the area within the so-called 'nine-dash line' (Pogies, 2017). The PCA has made it clear that PRC's historical claim is not in line with current international law. So, PRC claims that it has a legitimate right oversea territory in the South China Sea based its historical claim was dismissed by the court. In the aftermath of the decision, PRC is still continuing to uphold its historical claims in the region, meaning that the PCA decision is non-enforceable since PRC as one of the biggest militaries, politics and economic power is unwilling to respect international law. This makes meaningful negotiation and final solution of the dispute will be out of reach (Ba, 2003; Yu \& Shu, 2019). Putting aside the motivation or reason behind the revival of the work of the historical claim justification for the South China Sea. The lack of legal-based for historical claims to the Islands on the Pacific Ocean made PRC to use its own narrative to justify South China Sea claims $(\underline{\mathrm{Ba}, 2003})$.

\section{RESEARCH MATERIALS AND METHODS}

The research is concerned with both the current state of law and how the law used to be in the future involving the political and factual condition as a factor that determines the law created. This article is an extraction of desk research of legal materials, including regional or multilateral treaties and national law. This research also considers sources of international law stipulated under article 38 of the Statute of International Court of Justice, named customary international law, the general principle of law, judicial decision, and teaching of the most highly qualified publicist.

\section{RESULTS AND DISCUSSION}

\section{ASEAN Dispute Mechanism for Economic Dispute with PRC}

Economic relations between ASEAN as an international organization, including each of its member states in the modern era has been growing since the medieval of the 1990s. From 1995 until 2005, for example, the trade in goods growth hit a total increased of USD 100.2 billion, which further increased to a total of USD 368 billion in 2016. This means that an amount of $18 \%$ per year growth was achieved. The sustainability of the growth was secured by the ASEAN- China Free Trade Area (ACFTA) agreement between the two. The ACFTA agreement aims to promote investment flows between parties in several sectors, such as construction, tourism, business services, travel, and transportation (Swee-Hock, 2007) and could be an efficient way of attracting inward Foreign Direct Investment (Li \& Maani, 2018), and for several sectors, ACFTA indeed gave a positive impact (Romadona \& Pujiati, 2018). PRC has offered several incentives including the provisions of the 'initial harvest' which gave ASEAN a rapid tariff reduction, including a partial liberalization of the agricultural sector for three years (Pfaff, 2016).

This framework is still largely on track, although there are still important concerns in the country that can still complicate the process. But the most significant PRC's partners are the relatively new members of ASEAN which are Laos, Myanmar, and Cambodia. As the developing economic power, these countries are especially concerned about whether the ACFTA will 
open their domestic market to be flooded with cheap Chinese products, which have better quality than their local products. Meanwhile, older ASEAN member states are concerned that ASEAN would face a 'development gap' between old and new ASEAN members. Realizing this concern, PRC has agreed to extend the status of the Most Favored Nations to new ASEAN members, who are not yet members of the World Trade Organization (WTO), as well as 'special and different treatment and flexibility in implementation' which gives additional 5 years for the new members, until 2015, to comply with the international agreement. Consequently, the new members of ASEAN were able to take benefit of the initial entrance to the PRC's domestic market before they open their national gate to PRC's business, making a real competition to begin (Pfaff, 2016). On the PRC side, the ACFTA becomes an important, political, and economic interest (Yuzhu, 2012). In addition to shared concerns about economic globalization and regional integration of Europe and North America, PRC-ASEAN relations gave PRC the influence of larger negotiations face to face with other regional groups and in global forums such as the World Trade Organization. Under the Domestic considerations, the PRC government plays also an important role because the legitimacy of the Chinese Communist Party relies more on its ability to maintain PRC national economic growth. At the very least, PRC has an interest in creating and maintaining a stable and friendly regional environment so that it can focus on domestic challenges going forward. One of the most important challenges is a safeguard in the form of an effective and fair dispute resolution mechanism between ASEAN Members and PRC. The ACFTA is, in theory, is beneficial for both sides, intriguingly, not a single dispute has been tried by this mechanism and it is unclear whether or when it will be used in the future (Sookhakich, 2019).

Meanwhile, despite all the economic development, The Charter of The Association of Southeast Asian Nations or widely known as the ASEAN Charter was not designed to cover dispute resolution mechanisms, including the one for economic disputes. There are three biggest problems personified in the ASEAN Charte: Legal personality, privileges and immunities, and dispute settlement mechanism (Chalermpalanupap, 2009). To that, the ASEAN Charter needs to be equipped with other international instruments. Conflict prevention and settlement is one of the main elements of ASEAN Political-Security (PSC) as one of the main pillars of ASEAN. Therefore, ASEAN must take part in conflict settlement regarding the South China Sea. It is inside the pale of ASEAN's responsibilities and interests (Khanh, 2016). ASEAN's prophylactic diplomacy is one of the most important circumstances for all countries to use and gain from in terms of joint national interest and to deter wars (Sokla, 2019).

To fill the gap of dispute resolution mechanism of the ASEAN Charter, political and security cooperation is vital to prevent conflicts. On 4 November 2002, ASEAN together with PRC signed the Declaration of Conduct of the South China Sea, which set ASEAN-PRC commitment to resolve the South China Sea dispute in a peaceful way under international law. 9 years later, ASEAN-China Ministerial Meeting in Bali, Indonesia adopted 'The Guidelines for The Implementation of the Declaration of Conduct of the South China Sea'. PRC's decision not to accept the PCA award in 2016 showed that the two international instruments are not effective. Learn from the security area, the economic cooperation between ASEAN and PRC is questioned. PRC's investments in ASEAN member countries under the BRI Initiative to a certain extent is governed by contract, however, by its very nature, the BRI initiative requires economic cooperation between states. In that situation, PRC and the host states receiving investment from PRC need a robust fair international dispute resolution mechanism. The dispute resolution terms are normally stated in the bilateral investment contract and this needs to be fair.

In June 2018, PRC's Supreme Court established new branches as new Belt Road Courts. International Commercial Court of China (CICC) was established in two different locations, in Shenzhen and Xi'an. The court will hear disputes related to the BRI. Shenzhen CICC has jurisdiction to hear BRI maritime road and XI'an CICC can be used for Land BRI (Willan, 2018). The two new courts have a vital problem relating to the forum of access and fairness because it is located in PRC and mainly falls under PRC's legal system. The doubt then led to a new international Commercial Arbitration Initiative in Asia ( $\underline{\mathrm{Gu}}$, 2018).

Arbitration is argued to constitute a primary vehicle of international commercial dispute resolution in an economically integrated ASEAN with BRI. Gu (2018) concludes that the BRI promises a specific opportunity to increase cooperation in economic and cross-border integration to the development of infrastructural projects in Asia. According to that, international commercial arbitration with all of its benefits has been considered for the primary way to resolve international dispute arises from the BRI initiatives.

There are three types of disputes that may arise under the BRI projects: (1) Disputes between states; (2) State- Investor disputes; and (3) Disputes between investors since the BRI projects mainly rely on public-private partnership scheme. The CICC will have no jurisdiction to solve a case between states since the state has state immunity and the governmental organs therein have diplomatic immunity, that makes the state's organs, such as a president, or ministry immune from other state jurisdiction. The state and diplomatic immunity is a widely accepted practice and accepted as customary international law. Since the 1920s, states have been engaged in trading activities. The state act is categorized as 'Iure Gestionis' as well as exercising public functions categorized as 'Iure Imperii'. Ever since states have moved to practice a doctrine of restrictive immunity by which states only allow to act under Iure Imperii. Study shows that national and international legal instruments 
agreed between states uses the doctrine. National legislation such as the United States Foreign Sovereign Immunities Act 1976 and State Immunity Act of the United Kingdom 1978 uses the restrictive doctrine. International treaties also do the same, which evident in the 1972 European Convention on State Immunity and the United Nations Convention in Jurisdictional Immunities of State and their Property 2004 (Harris, 2010). The two customary international laws thus, prevent the CICC to hold jurisdiction over states or state's organs under the BRI project.

Karen Gilchrist predicted that The PRC's BRI could put the global financial system in a risky situation. Since PRC is willing to lend its money in the form of investment to countries that could not afford to pay back in a timely manner, the BRI drag the countries into debt risks. In ASEAN, we have at least three Countries proven to face this risk at the earliest stage of BRI, which is Cambodia, Myanmar, and Laos. Outside ASEAN, china keeps lending its money countries that are unlikely to pay because of their internal condition, such as Djibouti, Pakistan, Sri Lanka, and the Maldives. In Sri Lanka, PRC invested 1,5 billion for a new port, in 2017 Sri Lanka could not pay PRC so they gave a 99 years lease to PRC to control the port. A similar condition also happened in Myanmar as an ASEAN country and threatens other ASEAN Countries which has been involved in the BRI deal with PRC.

Under the international law system, the concept that regulates the condition when a state cannot fulfill its international obligation is the 'state responsibility'. Every internationally wrongful act of a State entails the international responsibility of that state (Article 1, Articles on Responsibility of States for Internationally Wrongful Acts 2001); this is the basic principles that also govern the BRI projects where a dispute may begin when a state is violating the international obligation to PRC, as shown in Sri Lanka, Djibouti, and Pakistan. Permanent Court of International Justice, PCIJ applied the principle in the Phosphates on Morroco Case, where it affirmed that when a state commits an internationally wrongful act the international responsibility is established. As a legal consequence of the international responsibility of the state, the responsible state is under an obligation not to continue or repeat the wrongful act(s) (Article 30, Articles on Responsibility of States for Internationally Wrongful Acts 2001) and to make full reparation for the injury caused (Article 31, Articles on Responsibility of States for Internationally Wrongful Acts 2001).

The fair economic dispute resolution mechanism, including alternative dispute resolution, can provide a win-win solution (Carneiro, 2019), which able to prevent the case of Myanmar and Sri Lanka to happen. When a country cannot compensate for PRC obligations, they can resort to a fair dispute resolution mechanism instead of fall into the death trap of negotiation that leaves nothing else than give their control over the territory to the PRC. However, the mechanism needs an additional commitment of PRC to the rule of law. PRC's rule of law will bring PRC equal with nations which have dominated the international governance traditionally. PRC must demonstrate a commitment to promote and adhere to the rule of law, inside PRC's national border and throughout international boundaries.

\section{South China Sea Dispute's Implication towards ACFTA}

PRC has never been aggressive to ASEAN as an international organization since the two powers agreed and ratified a treaty of amity and cooperation in 2003, which shows PRCs commitment to respect the friendly relation which is one of the most important principles among ASEAN member states. However, the relations between the PRC with each member state of ASEAN were escalating because of the South China Sea claims. The claims are regarded as a threat to sovereignty and noninterference principle for several member states of ASEAN, among them is the Philippines became the most vocal power in ASEAN against PRC. ASEAN encountered a quandary of non-interference in maintaining Southeast Asian regional order stable (Aizawa, 2019). ASEAN was divided into the South China Sea Issue; even the Asian Regional Forum (ARF) cannot handle the situation. The PRC then came up with an initiative of joint development in the South China Sea with ASEAN member states, however, for now, claimants of ASEAN Members from disputed territories are still cold stoned. In the past, conflicts between the Philippines, PRC, and Vietnam escalated to claim the control of islands in the South China Sea. Although, in 2005, state-owned oil companies from three countries entered into a 3-years agreement for joint exploration for oil and gas in the disputed area where security issues involving PRC is still exist which become challenges for ASEAN (South China Sea Expert Working Group, 2019).

The situation on the South China sea attracts attention form ASEAN member states because PRC shows superiority by undermining international law. Despite sovereignty claim, delimitation issues, environment, and natural resource exploitation problem, major armed conflict is still unlikely (Wang, 2015; Kaye, 2017; Weissmann, 2015). In terms of military supremacy, China still falls behind the USA. As an alternative, China is cleverly using asymmetric strategies the Belt and Road Initiative (BRI) (Paul, 2018). PRC's relation with the Philippines was increasingly hostile after the dispute brought to the PCA on the South China Sea. For managing the conflict PRC and ASEAN have to have political moves so the tensions can be isolated, and this is done by maintaining and further developing more resilience economic cooperation between the two. The issue of South China Claim is also related to the economic issue given that there are abundant natural resources that vital for ASEAN member states economics (Kingdon, 2015). In any conflict, there are interests that stimulate a party's claimed situation. Identifying and focusing on these interests is the unsurpassed method to resolve the conflict. 
Each state has interests when emphasizing its claiming position (Nguyen, 2017). So, PRC needs ASEAN as a partner for strategic economic cooperation and this is the main negotiating position to promote peaceful dispute settlement for territorial claim conflict. In this regard, ASEAN and PRC have to close their relation to power outside the two parties, because outside intervention on these issues will complicate the problem. The world's major powers involvement leaves ASEAN a little space to act constructively in managing disputes by building trust for working together closely on maintaining regional peace.

Any activity to further improve exchange relations among ASEAN and PRC is still possible inside the ACFTA system, so this grows a conviction that the monetary ties among China and ASEAN states contribute to the South China Sea resolution (Jenner \& Thuy, 2016). It pushes the parties to build venture relations between them inside the ACFTA system. As referred before, ASEAN as a region is the key also for realizing PRC's One Belt One Road (OBOR) infrastructure development. Since 2013, OBOR has steadily gained international interest (Jeganaathan \& Jeganaathan, 2017; Lanjian \& Wei, 2015; Ruankham, 2018). With PRC's innovation of technology and product and ASEAN domestic demand (Chen, n.d.), PRC and ASEAN will have it as an opportunity to forge two side investment and trade.

Although the problem of the South China Sea affects the BRI negatively, the impact is limited and manageable it will not entirely ruin the initiative (Abdul Kadir, 2017). The South China Sea dispute is only temporary. The escalation on the issue becomes more intense but armed contacts in this South China Sea territory are unlikely to happen. The states involved in the dispute fearing the high risks of military intervention with one of the biggest military powers in mother earth, and therefore do not want to trigger open military contact with PRC (Benthem, 2018; Xiao, 2015). The tension tends to fall again from its current peak (Abdul Kadir, 2017). In addition, tensions in the pacific can be managed. While the transient nature of the problem in the South China Sea may not lead to a final resolution for the dispute, the South China Sea problem is relatively stable, meaning that no states can change the problem structure easily. In view of this, states will tend to strengthen communication and dialogue to avoid conflict. The activities include the establishment of think tank dialogue and the development of mutually beneficial economic and trade cooperation. All of these supports help to create a peaceful solution to the problem of the South China Sea (SCS).

The SCS dispute has to be localized with the division of economic relations and political relations, since focusing only on a territorial dispute in SCS is likely to ruin the entire ASEAN-China geopolitical relation, which at the end both parties get a zero-sum as a result of the 'zero sum game'. Both parties have to be aware that political or even military rises within the SCS will weaken the economic relation, including huge trade and investment built throughout the past decades, including the BRI projects which were confirmed by Wag Yi, PRC's Prime Minister, as the project that require ASEAN as one of the prioritized partners. One common argument in Chinese analyses of BRI is that regional integration will contribute to a more stable security environment (Wuthnow, 2017). Interconnectivity projects were initiated which include fast train-railways construction Laos, Thailand, and Indonesia. Both parties also agreed to strengthen regional-state relations on the free trade area for liberalizing trade and investment even more with the RCEP. Several maritime cooperation is also vital, including security cooperation and marine environmental protection (Amer, 2014; Singh, 2016; Yamaguchi, 2016). The contest of ASEAN-China partnership mentioned proof that ASEAN and PRC are not yet completely separated because of the SCS issue. Based on it, a conviction should not drastically block the economic partnership of the two or destroy the bridges between different legal systems (Vadi, 2015). Instead, the initiative will fundamentally promote peace and stability in the region (Rizal, 2014).

\section{CONCLUSION AND RECOMMENDATIONS}

PRC has become the largest market for most of its neighboring economies and has become an increasingly vital trade and foreign direct investment supplier for them. PRC and its neighboring countries are connected by a production network supported by investment and trade flows. It is a general truth that developing cooperative and harmonious neighbor relationships is very important for economic partnerships (Deardorff, 2014; Fukunaga, 2015; Lu et al., 2014). Yet PRC and its neighboring regional organization or states, especially ASEAN member states, was challenged by SCS conflict. PRC government needs to implement good diplomacy with neighboring countries as a basic requirement to realize the fair BRI project. PRC's stance by ignoring the PCA awards on SCS shows that the hard way of using international law is difficult to be implemented. Then the hope to resolve the conflict would be using current economic diplomacy in the forum discussing the BRI project or comprehensive free trade area. This is more flexible than the contentious case at international court and hopefully can open a win-win solution.

China and ASEAN countries should take a long-term perspective on the relationship between regional security and economic development. However, ASEAN was not designed to cover a dispute resolution mechanism, including the one for economic disputes with PRC (Jayadi, 2016; Koesrianti, 2016; Puig \& Tat, 2015). To that, the ASEAN Charter needs to be equipped with other international instruments. Learn from the security area, the economic cooperation between ASEAN and PRC is questioned. PRC's investments in ASEAN member countries under the BRI Initiative to a certain extent is governed by 
contract, however, by its very nature, the BRI initiative International Commercial Court of China requires economic cooperation between states. The newly established PRC's International Commercial Court of China (CICC) was established in two in Shenzhen and Xi'an cannot satisfy that they will guarantee access and fairness because it is located in PRC and mainly fall under PRC's legal system. The doubt then led to a new international Commercial Arbitration Initiative in Asia. Arbitration is argued to constitute a primary vehicle of international commercial dispute resolution in an economically integrated ASEAN with BRI (Morton \& Blackmore, 2001). The fair economic dispute resolution mechanism will prevent the case of Myanmar and Sri Lanka to happen. When a country cannot pay PRC obligations, they can resort to a fair dispute resolution mechanism instead of fall into the death trap of negotiation that leaves nothing else than give their control over the territory to the PRC. Lastly, PRC must demonstrate a commitment to promote and adhere to the rule of law, inside PRC's national border, and throughout international boundaries.

\section{LIMITATION AND STUDY FORWARD}

The time frame of the study limits the coverage of this article which only covers the development from 2019 backward. As the proposal of this research is to initiate a new legal instrument that governs safe and fair economic dispute resolution, should new legal instruments within ASEAN come into force, a continuance study will be needed. This research also does not cover the third pillar of ASEAN named socio-culture. Additional research is vital to enrich the analysis in the PoliticalSecurity and Economic perspective in this study.

\section{ACKNOWLEDGEMENT}

The research was done with the support of fellows at the Universitas Padjadjaran especially Garry Gumelar and Resha Roshana Putri. The writers would like to express their gratitude for her enormous help and contribution in writing this article.

\section{AUTHORS CONTRIBUTION}

The first author, Prita Amalia is the main researcher and writer in the study started in 2018 as she arranged and managed to set up a research team right after PCA ruling on South China Sea Dispute awarded. Danrivanto Budhijanto contributed a significant amount of study materials as well as writing the outlining critical thinking framework of the study and the article. Under the supervision of and consultation with Prof. An An Chandrawulan the analytical part of this article was enriched.

\section{REFERENCES}

1. Abdul Kadir, R. (2017). South China Sea and ASEAN-China Relations: Joint Development in the South China Sea? https://css.ethz.ch/content/dam/ethz/special-interest/gess/cis/center-for-securities-studies/resources/docs/ISPSW487\%20Kadir.pdf

2. Adnyana, I. M. (2016). Riview skema acfta terhadap ekspor Indonesia ke tiongkok, Hong Kong dan ASEAN. Jurnal Populis, 75-92.

3. Aizawa, N. (2019). Beyond the non-interference dilemma: The Indonesian Initiative on ASEAN charter, Nargis crisis and regionalism. Australian Journal of Politics and History, 65(3), 412-429. https://doi.org/10.1111/ajph.12590

4. Alleyne, A., Zhang, Z., \& Mu, Y. (2020). Sustaining International Trade with China: Does. Sustainability. 12, 5969. https://doi.org/10.3390/su12156159

5. Amer, R. (2014). China, Vietnam, and the South China Sea: Disputes and dispute management. Ocean Development and International Law, 45(1), 17-40. https://doi.org/10.1080/00908320.2013.839160

6. Benthem, Y. (2018). China's role in the ASEAN regional forum: A search for peace? An analysis of China's political behaviour in the South China Sea dispute through a realist lens. Retrieved September 1, 2020, from https://dspace.library.uu.nl/handle/1874/366994

7. Blizkovsky, P. (2013). Economic governance: What can the EU and ASEAN learn from each other after the economic crises? Journal of Southeast Asian Economies, 30(1), 1-18. https://doi.org/10.1355/ae30-1a

8. Booth, A. (2011). China's economic relations with Indonesia: Threats and opportunities. Journal of Current Southeast Asian Affairs, 30(2), 141-160. https://doi.org/10.1177/186810341103000207

9. Carneiro, C. d. (2019). Alternative dispute resolution and the WTO. Retrieved September 1, 2020, from https://link.springer.com/chapter/10.1007/978-3-030-03263-0_10

10. Chalermpalanupap, T. (2009). The ASEAN secretariat and legal issues arising from ASEAN charter. Indonesian Journal of International Law, 6(2), 89-92. Retrieved July 1, 2020, from https://neliti.com/publications/39289/theasean-secretariat-and-legal-issues-arising-from-asean-charter

11. Chau, K. (2018). Resolving the South China Sea Dispute. The Regionalist.

12. Chen, C. Y. (2016). "Belt and Road initiative and possible impacts on the South China Sea issue. International Relations and Diplomacy, 10, 7-10. https://doi.org/0.17265/2328-2134/2017.12.002

13. Chen, J. (n.d.). Chinese law: Context and transformation. Martinus Nijhoff Publishers. 
14. Cheng, L. K. (2016). Three questions on China's "belt and road initiative". China Economic Review, 40(40), 309313. https://doi.org/10.1016/j.chieco.2016.07.008

15. Cook, M. (2014). Comparing institution-building in East Asia: Power politics, governance and critical junctures. Contemporary Southeast Asia: A Journal of International and Strategic Affairs, 36(3), 48-93. https://doi.org/10.1355/cs36-3k

16. $\mathrm{Ba}, \mathrm{A}$ (2003). Renavigating relations for a 21st-century Asia. 18(4), 623-628. https://doi.org/10.1525/as.2003.43.4.622

17. Deardorff, A. V. (2014). Trade Implications of the trans-pacific partnership for ASEAN and other Asian countries. Asian development review, 31(2), 1-20. https://doi.org/10.1162/ADEV a 00035

18. Dellios, R., \& Ferguson, R. J. (2017). The human security dimension of China's Belt and Road Initiative. The Journal of Men's Studies, 7(3), 48-62. https://doi.org/10.5539/jms.v7n3p48

19. Fukunaga, Y. (2015). ASEAN's leadership in the regional comprehensive economic partnership. Asia \& the Pacific Policy Studies, 2(1), 103-115. https://doi.org/10.1002/app5.59

20. Gu, W. (2018). China's belt and road development and a new international commercial arbitration initiative in Asia. Vanderbilt Journal of Transnational Law, 51, 1305-1308.

21. Haar, E. V. (2011). Philippine trade policy and the Japan-Philippines Economic Partnership Agreement (JPEPA). Contemporary Southeast Asia: A Journal of International and Strategic Affairs, 33(1), 113-139. https://doi.org/10.1355/cs33-1e

22. Harris, D. (2010). Cases and materials on international law. Sweet and Maxwell.

23. Hew, D. (2007). Brick by brick: The building of an ASEAN economic community. Institute of Southeast Asian Studies. https://doi.org/10.1355/9789812307347-007

24. Jayadi, A. (2016). Dispute Settlement Mechanisms Under the ASEAN Legal Frameworks. Indonesia Law Review, 6(2), 263-264. https://doi.org/10.15742/ilrev.v6n2.231

25. Jeganaathan, J., \& Jeganaathan, J. (2017). 'OBOR' and South Asia: Can India and China Cope with the emerging 'New Normal' in the region? Fudan Journal of the Humanities and Social Sciences, 10(2), 161-178. https://doi.org/10.1007/s40647-017-0171-1

26. Jenner, C., \& Thuy, T. (2016). The south China sea. Cambridge University Press. https://doi.org/10.1017/CBO9781139963084

27. Joseph, C. (2001). Sino-ASEAN relations in the early 21st century. Contemporary South - East Asia, 23(3), 420452. https://doi.org/10.1355/CS23-3C

28. Kaye, S. (2017). The law of the sea convention and sea level rise after the South China Sea arbitration. International Law Studies, 93, 423-445.

29. Khanh, T. (2016). The role of ASEAN in the East sea conflict prevention. Vietnam Social Sciences, 4, 1-10.

30. Kingdon, E. (2015). A case for arbitration: The Philippines' solution for the South China Sea dispute. Boston College International \& Comparative Law Review, 38(129), 129- 157.

31. Koesrianti, K. (2016). Rule-based dispute settlement mechanism for ASEAN economic community: Does ASEAN have it? Hasanuddin Law Review, 1(2), 182-194. https://doi.org/10.20956/halrev.v1n2.303

32. Kristine, D. (2009). ASEAN protocol on enhanced dispute settlement mechanism. Indonesian Journal of International Law, 6(2), 1-10.

33. Laksmana, A. (2016). The domestic politics of Indonesia's approach to the tribunal ruling and the South China Sea. Contemporary Southeast Asia, 38(3), 382-388.

34. Lanjian, C., \& Wei, Z. (2015). China OBOR in perspective of High-speed Railway (HSR) — Research on OBOR economic expansion strategy of China. Advances in Economics and Business, 3(8), 303-321. https://doi.org/10.13189/aeb.2015.030803

35. Li, Q., \& Maani, S. A. (2018). Detecting positive effects of the ASEAN-China free trade agreement on foreign direct investment. International Economics and Economic Policy, 15(1), 69-87. https://doi.org/10.1007/s10368016-0366-y

36. Lu, Z., Yan, T., \& Deng, X. (2014). EU-China economic relations: Interactions and barriers. Review of European Studies, 6(4), 12-19. https://doi.org/10.5539/res.v6n4p12

37. McKinsey. (n.d.). Understanding ASEAN: Seven things you need to know. Retrieved from https://www.mckinsey.com/industries/public-sector/our-insights/understanding-asean-seven-things-you-need-toknow

38. Morton, B., \& Blackmore, G. (2001). South China sea. Marine pollution bulletin, 42(12), 1236-1263. https://doi.org/10.1016/S0025-326X(01)00240-5

39. Munandar, J. M., \& Firmansyah, D. (2018). The role of digital marketing in improving SME's product competitiveness in The ASEAN Economic Community (AEC) (Case study in Indonesia). Journal of Administrative and Business Studies, 4(4), 206-218. https://doi.org/10.20474/jabs-4.4.3 
40. Nguyen, H. (2017). Principled Negotiation: The Final Answer to the South China Sea Dispute. Texas A\&M Law Review, 287-314. https://doi.org/10.37419/LR.V4.I2.6

41. O'Rourke, R. (2016). Maritime Territorial and Exclusive Economic Zone (EEZ) disputes involving China: Issues for Congress. Congressional Research Service, 7, 57-70.

42. Paul, T. V. (2018). ASEAN and soft balancing: South China Sea as zone of peace? Retrieved August 29, 2020, from https://dr.ntu.edu.sg/handle/10220/44806

43. Pfaff, L. G. (2016). The dynamics of Chinese expansion in the South China Sea. Journal of Applied Business and Economics, 18(1), 63-70.

44. Pogies, C. R. (2017). UNCLOS and the South China Sea arbitration. Into lawfare's abyss? ASIEN The German Journal on Contemporary Asia, 97, 1-10.

45. Portal, A.-C. (n.d.). The trade data between ASEAN and China (million dollars). http://www.aseancn.org/index.php? $m=$ content $\& \mathrm{c}=$ index \&a $=$ show \&catid $=245 \& \mathrm{id}=105$

46. Puig, G. V., \& Tat, L. T. (2015). Problems with the ASEAN free trade area dispute settlement mechanism and solutions for the ASEAN economic community. Journal of World Trade, 49(2), 277-308.

47. Rizal, Y. (2014). A Maritime silk road and Indonesia's perspective of maritime state. CSIS working paper series.

48. Romadona, I., \& Pujiati, A. (2018). Trade creation and trade diversion analysis as impact of acfta towards Indonesian Import. Economics Development Analysis Journal, 7(1), 53-59.

49. Ruankham, W. (2018). A rise of China's OBOR to the regional economy and power. Journal of Economics and Management Strategy, 4(2), 51-66.

50. Sabit, M. B. (2015). The Effects of Exchange Rate Volatility on ASEAN-China Bilateral Exports. Journal of Economics, Business and Management, 3(5). https://doi.org/10.7763/JOEBM.2015.V3.231

51. Schofield, C. H. (2016). A landmark decision in the south China Sea: The scope and implications of the arbitral tribunal's award. Contemporary Southeast Asia: A Journal of International and Strategic Affairs, 38(3), 339-347. Retrieved 8 7, 2020, from https://ro.uow.edu.au/lhapapers/3058

52. Singh, A. (2016). India's strategic stakes in the South China Sea. Asia Policy, 21(1), 14-20. Retrieved June 8, 2020 , from https://muse.jhu.edu/article/609170/pdf

53. Sokla, C. (2019). ASEAN's preventive diplomacy: What roles for ASEAN in the South China Sea and the rakhine state issues? The Open Journal of Political Science, 9(2), 434-457. https://doi.org/10.4236/ojps.2019.92024

54. Sookhakich, P. (2019). Limits and challenging factors of the dispute settlement mechanism in the light of ChinaASEAN Free Trade Agreement Perspective. Asian Political Science Review. https://doi.org/10.2139/ssrn.3459317

55. South China Sea Expert Working Group. (2019). A blueprint for cooperation on oil and gas production in the south China Sea. https://amti.csis.org/a-blueprint-for-cooperation-on-oil-and-gas-production-in-the-south-china-sea/

56. Sutiono. (2018). Dynamic equilibrium as Indonesia's defense diplomacy geo-strategy to address China-US sphere of influence dualism in ASEAN. International Journal of Humanities, Arts and Social Sciences, 4(4), 186-193. https://dx.doi.org/10.20469/ijhss.4.10004-4

57. Swee-Hock, S. (2007). ASEAN-China economic relations. Institute of Southeast Asian. https://doi.org/10.1355/9789812306562-003

58. Taguchi, H. (2015). Trade creation and diversion effects of ASEAN-plus-one free trade agreements. Economics Bulletin, 1856-1866.

59. Tampubolon, J. (2019). Indonesian export performance and competitiveness in The Asean-China Fta. WSEAS Transactions on Business and Economics, 16, 1-10. https://doi.org/10.2139/ssrn.3594970

60. Vadi, V. (2015). The migration of constitutional ideas to regional and international economic law: The case of proportionality. Northwestern journal of international law and business, 35(3), 55-57.

61. Wang, K.-H. (2015). Peaceful settlement of disputes in the south China Sea through fisheries resources cooperation and management. Maryland Series in Contemporary Asian Studies, 3, 1-10.

62. Weissmann, M. (2015). The South China Sea. ASIAN SURVEY, 55(3), 23-27. https://doi.org/10.1525/as.2015.55.3.596

63. Wildan, F., Yuliati, L., \& Luthfi, A. (2017). Analisis integrasi ekonomi Indonesia - China terhadap perekonomian Indonesia, sebelum dan sesudah AFTA. Journal of Research Economic and Management, 3, 1-10.

64. Willan, H. (2018). Dispute resolution. https://www.hfw.com/downloads/HFW-The-Belt-and-Road-InitiativeDispute-Resolution-along-The-Belt-And-Road-August-2018.pdf

65. Williams, J., Robinson, C., \& Bouzarovski, S. (2019). China's Belt and Road Initiative and the emerging geographies of global urbanisation. Retrieved June 7, 2020, from https://rgsibg.onlinelibrary.wiley.com/doi/full/10.1111/geoj.12332

66. Wuthnow, J. (2017). Chinese perspectives on the belt and road initiative: Strategic rationales, risk, and implications. National Defense University Press. 
67. Xiao, R. (2015). Toward a normal state-to-state relationship? China and the DPRK in Changing Northeast Asia. North Korean Review, 11(2), 63-72.

68. Yahuda, M. (2019). The international politics of the Asia-Pacific. Routledge. https://doi.org/10.4324/9781315543291

69. Yamaguchi, S. (2016). Strategies of China's maritime actors in the south China Sea. China perspectives, 3, 23-30. https://doi.org/10.4000/chinaperspectives.7022

70. Ye, Y. (2015). Global economic governance reenergized. https://worldscientific.com/doi/10.11 2/s2377740015500293

71. Yu, C. C., \& Shu, Y. L. (2019). The economic analysis of product substitutability and intimidation effect on vertical integration. Journal of Administrative and Business Studies, 5(4), 206-218. https://doi.org/10.20474/jabs-5.4.2

72. Yuzhu, Z. Y. (2012). ASEAN in China's grand strategy. Chinese Academy of Social Science, 4, 162-166.

73. Zhang, W. A. (2018). China's belt and road initiative: Changing the rules of globalization. Springer.

74. Zhao, S. (2018). China and the South China Sea arbitration: Geopolitics versus international law. Journal of Contemporary China, 1, 21-27. https://doi.org/10.1080/10670564.2017.1363012 